\title{
Pulmonary Toxicities and Treatment of Radiation Therapy
}

\author{
Emine Argüder ${ }^{1}$, Berna Akkuş Yıldırım², H. Canan Hasanoğlu³ \\ ${ }^{1}$ Clinic of Chest Diseases, Ankara Atatürk Training and Research Hospital, Ankara \\ ${ }^{2}$ Clinic of Radiation Oncology, Ankara Numune Training and Research Hospital, Ankara \\ ${ }^{3}$ Department of Chest Diseases, Ylldırım Beyazıt University Faculty of Medicine, Ankara
}

\begin{abstract}
Radiotherapy (RT), used for the treatment of cancers, such as lung cancer, lymphoma, breast cancer, bone marrow transplantation, and esophageal cancer, causes the exposure of lungs to radiation. Since the lungs are very sensitive to ionizing radiation, radiation-induced lung diseases due to radiation therapy are usually common. In this article, lung diseases secondary to RT and the diagnosis and treatment of these diseases were evaluated in light of the literature.
\end{abstract}

Keywords: Cancer, lung, radiotherapy, toxicity

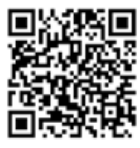

Received Date: 10.02.2013 Accepted Date: 21.05.2013

Available Online Date: 02.12.2014

Address for correspondence

Emine Argüder, Clinic of Chest Diseases, Ankara Atatürk Training and Research Hospital, Ankara, Turkey

E-mail: drgullu2000@gmail.com

C Copyright 2014 Turkish Respiratory Society (TRS) Eurasian J Pulmonol 2014

DOI: 10.5152/ejp.2014.39206

-Available online at www.eurasianjpulmonol.com

\section{INTRODUCTION}

The exposure of normal tissues, besides cancerous tissues, to radiation from the first days of radiotherapy (RT) application has been an important limiting factor. Although the incidence of radiation-induced normal tissue injury has diminished with the development of radiation oncology technology in recent years, it still goes on. In this review, general information about RT is given, and RT-induced toxicity types that develop in the lungs and therapies are explained.

\section{GENERAL INFORMATION}

RT is used for palliative, curative, adjuvant, and prophylactic purposes in cancer treatment. The aim during radiotherapy application is to reduce or remove tumor load while protecting normal tissue. The injury of normal tissue always poses the main obstacle to RT. In time, strategies, such as dose-volume modulation, image-guided RT applications, involved-field radiotherapy, and the use of lung disease-preventive agents, have been developed to overcome this problem

Thoracic RT may be conducted in cases, such as lung cancer, bone marrow transplantation, and esophageal cancer. Lungs are among the most sensitive organs to ionizing radiation, and this sensitivity is one of the most important dose-limiting obstacles of thoracic RT. Temporary sequential inflammatory events are seen in the lung tissue as a response to radiation exposure. Here, individual differences, by affecting the outcome, bring about the occurrence of normal or pathological responses. Radiation-induced lung injury is a progressive process, including inflammation and repair. The development of injury may be prevented and the development of new strategies for treatment may be possible by understanding the underlying mechanisms of the basic molecular damage caused by radiotherapy $(1,2)$.

Today, external RT (EBRT), brachytherapy, intraoperative RT (IORT), stereotactic RT (SRT), three-dimensional conformal RT (3D-CRT), intensity-modulated RT (IMRT), image-guided RT (IGRT), tomotherapy, cyberknife (robotic radiosurgery), boron neutron capture therapy, and hyperthermia are among RT applications. Location of the tumor, its histopathological feature, sensitivity to RT, the patient's undergoing surgical intervention, and his receiving chemotherapy are important for the preference of the appropriate technique (3). 
Table 1. RTOG traditional scoring system for lung injury secondary to radiation

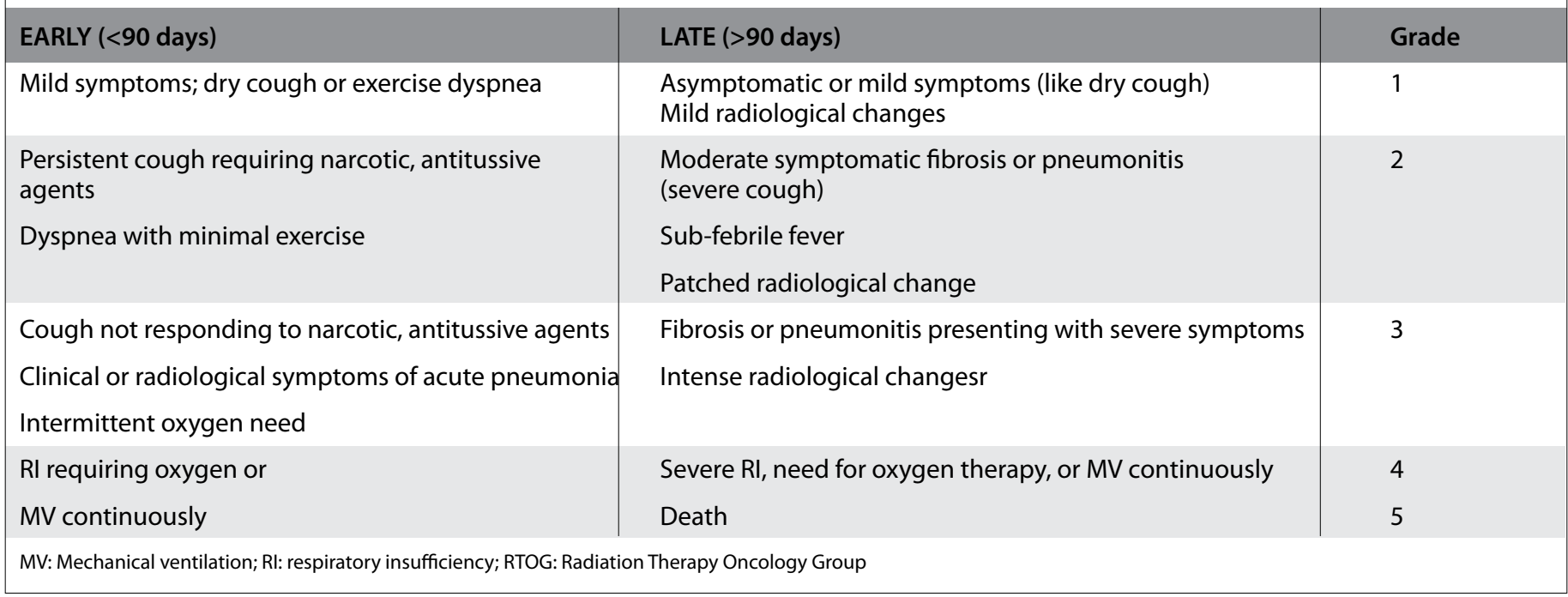

Radiation has an impact on the alveolocapillary unit of the lung according to the proliferation of cells. Endothelial, epithelial (particularly, type 2 pneumocytes producing surfactant), and reticuloendothelial system cells are more sensitive to radiation. Radiation gives damage to these cells by apoptosis and stimulation of stress response genes. Reactive oxygen (ROS) and nitrogen (RNS) production primarily causes the breakdown of DNA, lipid, and proteins and necrosis as a result (4-7). The DNA damage caused by ionizing radiation leads to apoptosis of type 1 and type 2 pneumocytes. Moreover, radiation-induced damage in the lung disrupts the epithelial and endothelial barrier. As a result of this damage, various inflammatory cells move to the damaged region. RT applied to the lung may cause hypoxia by reducing vascular density and lung perfusion. Additionally, activation transcription of some early and late response genes may be seen as a response to ionizing radiation in cells (8-10).

Transforming growth factor beta 1 (TGF- $\beta 1$ ) is a multifunctional peptide, playing a role in the pathogenesis of fibrosis, and has an important place in radiation-induced pneumopathy (5-7). Plasma TGF- $\beta 1$ level was first detected by Anscher et al. (11) as a predictor in normal tissue injury. Although serum interleukin (IL) 1, 6, 8, and 10 levels were correlated with radiation-induced lung damage, the very correlation could not be found in some studies (12-14).

Radiation damage in many cases is restricted to the radiation-applied region; it may develop in regions apart from the RT-applied region in some instances, and the best example of it is cryptogenic organizing pneumonia (KOP/BOOP) $(7,8)$. Partial lung irradiation sometimes may cause acute respiratory distress syndrome in spite of corticosteroid therapy (15). Other lung regions' being affected by the application of RT on the lungs locally is thought to be associated with a lymphocyte-mediated hypersensitivity reaction (16).

Radiation-induced lung damage causes respiratory disorders. The most common radiological finding is interstitial infiltrates in the RT-applied region. Furthermore, consolidation, nodullary, and pleural effusion may be also seen. This may lead to difficulty, especially in the progression of tumor progression and the differential diagnosis of the infection. Positron emission tomography (PET) may help in the differential diagnosis (18).

The most important factor influencing the development of radiation-induced lung damage is the lung volume exposed to radiation (19-21). Radiation application to both lungs is very rare. Total body irradiation may be conducted for bone marrow transplantation. Radiation pneumonia developing after low volumes of RT is milder and heals spontaneously. Understanding the real incidence of radiation pneumonia is difficult due to the change of the standards used for the identification and grading of the disease (22).

Radiotherapy-induced effects and the traditional scoring system developed by the Radiation Therapy Oncology Group (RTOG) are displayed in Table 2. Furthermore, the late effects in normal tissue subjective, objective, management criteria (LENTSOMA) toxicity criteria were identified by RTOG and the European Organization for Research on Treatment of Cancer (EORTC) (23-26). The Radiation Therapy Oncology Group determined the early and late toxicity period according to 90 days. However, there was difficulty in evaluating some radiation-induced pneumonias with this determination. The National Cancer Institute $(\mathrm{NCl})$ rearranged these side effects as common terminology criteria (CTCV3.0). The new CTCV3.0 was adopted in evaluating side effects for existing and future studies (Table 2) (27).

Most of the clinical studies of radiation oncology have focused on the dose-volume histogram (DVH) concept, which is one of the most important parameters to assess the three-dimensional conformal plan. The volume of tissue is divided into equal rates, and doses corresponding to these rates are calculated. Thus, the proportional dose distribution of tumor and normal tissue volume can be seen graphically. The dose-volume histogram is divided into two: differential and cumulative (28). One of the parameters assessed in lung DVH is the evaluation of the irradiated lung volume and the development of pneumopathy risk. The lower the volume, the smaller the risk of pneumopathy development. Hodgkin reported that radiation pneumonia risk decreased from $29 \%$ to $17 \%$ with involved-field radiotherapy for lymphoma (29). The use of DVH for predicting radiation pneumopathy was just based on anatomic data. Lung physiology or 
Table 2. CTC v3.0 criteria in the evaluation of side effects in radiation pneumonia (27)

\begin{tabular}{|l|l|l|l|l|l|}
\hline Side effect & Grade 1 & Grade 2 & Grade 3 & Grade 4 \\
\hline $\begin{array}{l}\text { Pneumonitis/pulmonary } \\
\text { infiltration }\end{array}$ & $\begin{array}{l}\text { Asymptomatic; there } \\
\text { are only radiological } \\
\text { findings }\end{array}$ & $\begin{array}{l}\text { Symptomatic, daily } \\
\text { life is not affected }\end{array}$ & $\begin{array}{l}\text { Symptomatic, daily } \\
\text { life is affected. } \\
\mathrm{O}_{2} \text { is required. }\end{array}$ & $\begin{array}{l}\text { There are life-threatening } \\
\text { threatening symptoms } \\
\text { Ventilator support is required }\end{array}$ & $\begin{array}{l}\text { Mortality } \\
\text { CTC: Common Terminology Criteria }\end{array}$ \\
\hline
\end{tabular}

the underlying disease of the patient was not considered. This may make the prediction difficult, especially in old and smoking patients with lung or esophagus cancer. The risk of radiation pneumopathy development is higher, since the perfusion rate of lower lobes in lower lobe lung cancer treatment is higher (30).

Dosimetric factors are used in tomography-based treatment planning. Therefore, before planning, lung volume is calculated mathematically by introduction of organs to the treatment device with the tomography conducted in the treatment position. Oetzel et al. (31) indicated by using mean lung disease (MLD) and normal tissue complication possibility (NTCP) that there was a correlation between radiation dose and the risk of lung damage. In another study, it was found that the quantity of lung volume, taking a dose of 20 Gy, was the most important factor in determining the incidence rate of radiation-induced lung injury $(31,32)$. Normal tissue complication possibility is used to predict the dose-volume relationship in lowdose-taking regions of tissue. Mean lung dose and NTCP are the best markers used to predict lung injury. In a study carried out, when only dosimetric factors were considered, it was found that a lung volume taking 5 Gy (V5) of $50 \%$ or above was an important factor for symptomatic pneumonia development (33).

In the guideline prepared by the European Respiratory Society (ERS) and the European Society of Thoracic Surgeons (ESTS), by stating that lung physiology can not determine the acute and long-term risks associated with thoracic radiotherapy definitely, the cut-off value for FEV $_{1}$ was reported to be 2 liters in simultaneous RT KT studies for locally advanced disease. Moreover, it was reported that in patients with chronic obstructive pulmonary disease (COPD), radiotherapy should not be performed at values below $1.2 \mathrm{lt}$.

Apart from radiation dose-volume parameters, factors related with the treatment (daily radiation fraction size, simultaneous chemotherapy application) are also important in radiation pneumopathy development. Although neoadjuvant chemotherapy (CT) does not increase radiation pneumopathy risk much, the risk increases significantly with simultaneous CT. The maximum tolerated dose of localized RT is generally 60-66 Gy. Higher doses were tried, however quitted due to the increase in complication rate (36-38). Gemcitabine, a chemotherapeutic agent,highly increases RT toxicity $(39,40)$. Moreover, the use of anthracyclines (like doxorubicin), methotrexate, and bleomycin during thoracic radiotherapy is contraindicated. It was reported that simultaneous chemoradiotherapy, when applied with taxanes (paclitaxel or docetaxel), was safer with regard to radiation pneumopathy development (41).

In a study, other factors apart from treatment were evaluated in radiation-induced lung damage development, and it was found that performance was associated with damage development. In another study, no relationship was found between age, gender, smoking history, diabetes, induction chemotherapy, simultaneous chemotherapy regimen, and damage. It was suggested that lung functions before treatment were important in lung damage development, and it was indicated that RT-associated damage development risk increased in cases with COPD and low $\mathrm{FEV}_{1}(35,42)$.

\section{Radiation Pneumonia}

Radiation pneumonia (RP) is characterized by high interstitial inflammation and alveolar exudates. It occurs 1-6 months after radiotherapy and generally recovers within 6-12 months. Age, localization of lesion, application of simultaneous or sequential chemotherapy, and smoking are known as risk factors for radiation pneumonia development. Chest radiography is not sufficient to evaluate changes that may develop with modern RT methods. RT-applied patients with pulmonary complaints should be evaluated with thorax computerized tomography $(\mathrm{CT})$. When interstitial infiltrate and/or ground-glass opacity is imaged, a differential diagnosis with infection diseases may be difficult. If fever accompanies in the presence of suspected moderate or severe pneumopathy, it may be necessary to make an examination to exclude possible infection $(22,44)$. The oxygen requirement of the patient should be evaluated with pulse oximetry or arterial blood gas. Measurement of diffusion capacity is among the diagnostic tests for evaluating the severity of impaired gas exchange. Although spirometric parameters in radiation pneumopathy are usually reversible, the probability of diffusion abnormalities reversing is low (45). Measurable changes in spirometry occur 2-3 months later, and after reaching the maximum level, they usually revert within $8-12$ months. A decrease is observed in lung volumes, compliance, and DLCO. There may be an increase after radiotherapy in lung volumes of patients whose tumors shrank apparently $(46,47)$. The response to corticosteroid in radiation pneumonia treatment is generally positive, and a dramatic response to the treatment is important in the differential diagnosis.

The corticosteroid treatment decision may be made if the clinical findings and test results are compatible with grade 2 or higher radiation pneumonia and the patient is symptomatic. Since there are no randomized controlled studies for radiation pneumonia developing in humans, the effectiveness of corticosteroids has been displayed with nonrandomized clinical studies $(14,48)$. There is no standard dose scheme for radiation pneumopathy. Usually, a daily dose of 1 $\mathrm{mg} / \mathrm{kg}$ prednisolone should be used for 2 weeks in severe radiation pneumonia (grade 3/4). Short-term hospitalization may be necessary for intravenous application of corticosteroids. Since early-onset radiation pneumonia occurring in a short time following completion of radiotherapy may have a serious course, more aggressive treatment approaches may be necessary (14).

Moderate radiation pneumonia (grade 2) may be treated with a lower dose of corticosteroid (0.5-0.75 mg/kg/day prednisolone); however, 
the patient should be followed closely to evaluate whether there is progress to a more severe picture (grade 3). After a couple of weeks, the dose should be gradually reduced to $10 \mathrm{mg}$ in 2 weeks. There may be symptomatic recurrences while reducing the corticosteroid dose. It is important to exclude concurrent infections when recurrence is observed. If it is a recurrence of RT pneumonia, the corticosteroid dose should be increased again $(14,48)$. Corticosteroid treatment should be given for a period of 2-4 months in grade 3 or grade 2 severe radiation-induced lung damage. Even though the effect of corticosteroids after 6 months is disputable, it may be necessary to give them for a longer period in some cases. The use of low-dose prophylactic antibiotic with corticosteroid is controversial.

Excluding an accompanying infection completely in all patients developing interstitial pneumonia after thoracic RT is difficult without applying bronchoscopy or other invasive diagnostic procedures (1). In high-dose corticosteroid-initiated cases after chemoradiotherapy, trimethoprim-sulfamethoxazole prophylaxis should also be initiated in the presence of deep lymphopenia (49). If there are findings in thoracic $\mathrm{BT}$ supporting concurrent infection, the use of broader-spectrum antibiotics is necessary. The prognosis of grade 1 and 2 RP is relatively better with careful supportive care and corticosteroid use (50). It is not known how the treatment will be in cases that are resistant to corticosteroid or if the use of corticosteroid is nonapplicable. Immunosuppressive therapy was tried in some similar cases $(51,52)$.

\section{Radiation Fibrosis}

Radiation fibrosis (RF) is chronic lung damage. TGF- $\beta 1$ discretion in tissue exposed to radiation leads to stimulation of fibroblasts and changes the lung structure by converting tissues to myofibroblasts. An inflammatory response follows this, and macrophage accumulation and activation occur. Increased oxygen consumption and vascular changes contribute to the development of hypoxia. Hypoxia formation further stimulates production of ROS and proinflammatory, profibrogenic, and proangiogenic cytokines. Consequently, the persistent nonhealing tissue response leads to the occurrence of chronic lung damage. Radiation fibrosis begins after a few months and progresses gradually over the years. It usually takes place 6-24 months after radiotherapy. RF can happen without an underlying acute pneumonia history. As patients may be asymptomatic, there may be a complaint of dyspnea to varying degrees (2). The radiological findings may be in the form of fibrotic changes in the RT field, scar-associated withdrawals in the lung parenchyma, traction bronchiectasis, volume loss, pleural thickening, and replacement in the trachea and mediastinum (1).

The treatment of radiation-induced pulmonary fibrosis is a supportive treatment, and it includes oxygen support, antibiotics in the presence of infection, and a bronchodilator and diuretics when necessary. In order to provide sufficient oxygen for the tissue, if required, it is necessary to prescribe cardiac and blood pressure drugs and heal anemia if present. It is not clearly known whether pulmonary rehabilitation programs are useful or not. If the patient remains immobile because of respiratory insufficiency, deep-vein thrombosis prophylaxis should be applied. Smoking should be definitely avoided (1).

\section{Bronchiolitis Obliterans Organizing Pneumonia}

It is a rare pulmonary disease and infection, and toxic agent inhalation and exposure to radiation are among the causes of it. In the connec- tive tissue reaching from the alveoli to bronchia a patchy distribution with intraluminal plugs is observed. The development mechanism of organized pneumonia after radiotherapy is not known completely (53). The first radiological changes in the lung receiving radiotherapy are in the forms of diffuse patchy ground-glass appearance in general and consolidation fields, including air bronchograms. Ambulant featuring of radiological findings is important in the differential diagnosis for OP. Increased sedimentation with polymorphonuclear leukocytosis is found as the laboratory findings. Positron emission tomography can be useful in the differential diagnosis. Transbronchial biopsy or open lung biopsy can be performed for the final diagnosis (54). The bronchoalveoler lavage (BAL) finding is often in the form of lymphocytic alveolitis (55). It may be confused with RP in the differential diagnosis. Organized pneumonia tends to occur a few months after RT is completed. It often takes longer than RP and usually gets better within 1 year. Although radiation pneumonia is restricted in the RT-applied region, ambulant alveolar opacities are seen in OP.

In the treatment, $1 \mathrm{mg} / \mathrm{kg}$ corticosteroid is used for 1-3 months at the beginning; then, $40 \mathrm{mg} /$ day corticosteroid is used for 3 months; and finally, $10-20 \mathrm{mg} /$ day corticosteroid is used for a year. The response to corticosteroid therapy is good. Recovery is observed clinically in 1 week and radiologically in 2-4 weeks. Recurrence can occur in treatments lasting shorter than 1 year $(53,54)$.

\section{Eosinophilic Pneumonia}

Almost all patients developing eosinophilic pneumonia after radiotherapy have a history of asthma or allergy. Symptoms in eosinophilic pneumonia are non-specific. Peripheral alveolar opacities are observed in the chest radiography. The clinical and radiological symptoms of eosinophilic pneumonia and OP are similar, and both respond to corticosteroid very well. The presence of eosinophils in the peripheral blood and alveoli is evaluated on behalf of eosinophilic pneumonia in the differential diagnosis (57). In eosinophilic pneumonia, there are CD4+ T helper cells (Th2) activated in the lung, and these are held responsible for antigenic stimulation (58).

\section{Radiation "Recall Phenomenon"}

Radiation "recall phenomenon" (RRF) is a rare inflammatory reaction that occurs as a response to trigger agents in the previous radiotherapy site. However, its etiology and pathogenesis are not well known. It is mainly seen with chemotherapeutic agents (59), the most common ones of which are taxanes, anthracyclines, gemcitabine, and erlotinib. However, it has been reported that it is also observed with tuberculosis drugs, antibiotics, tamoxifen, and simvastatin (60-63). Radiation "recall phenomenon" is generally seen in skin exposed to radiotherapy, but it has been also found in the lung, gastrointestinal system, muscle, central nervous system, and supraglottic region (64).

There are some hypotheses on the development mechanism of RRF. One of them is the development of a reaction associated with recall in cells going on to live in the previous RT site, after cytotoxic therapy is given following RT. An alternative hypothesis is that a permanent mutation secondary to radiation can develop in cells continuing to live in the RT site.

In the diagnosis of radiation "recall phenomenon," the presence of a history of chemotherapy after thoracic radiotherapy, radiological findings, and clinical condition are important. Typical radiological 


\section{A history of radiotherapy+ Respiratory complaints}

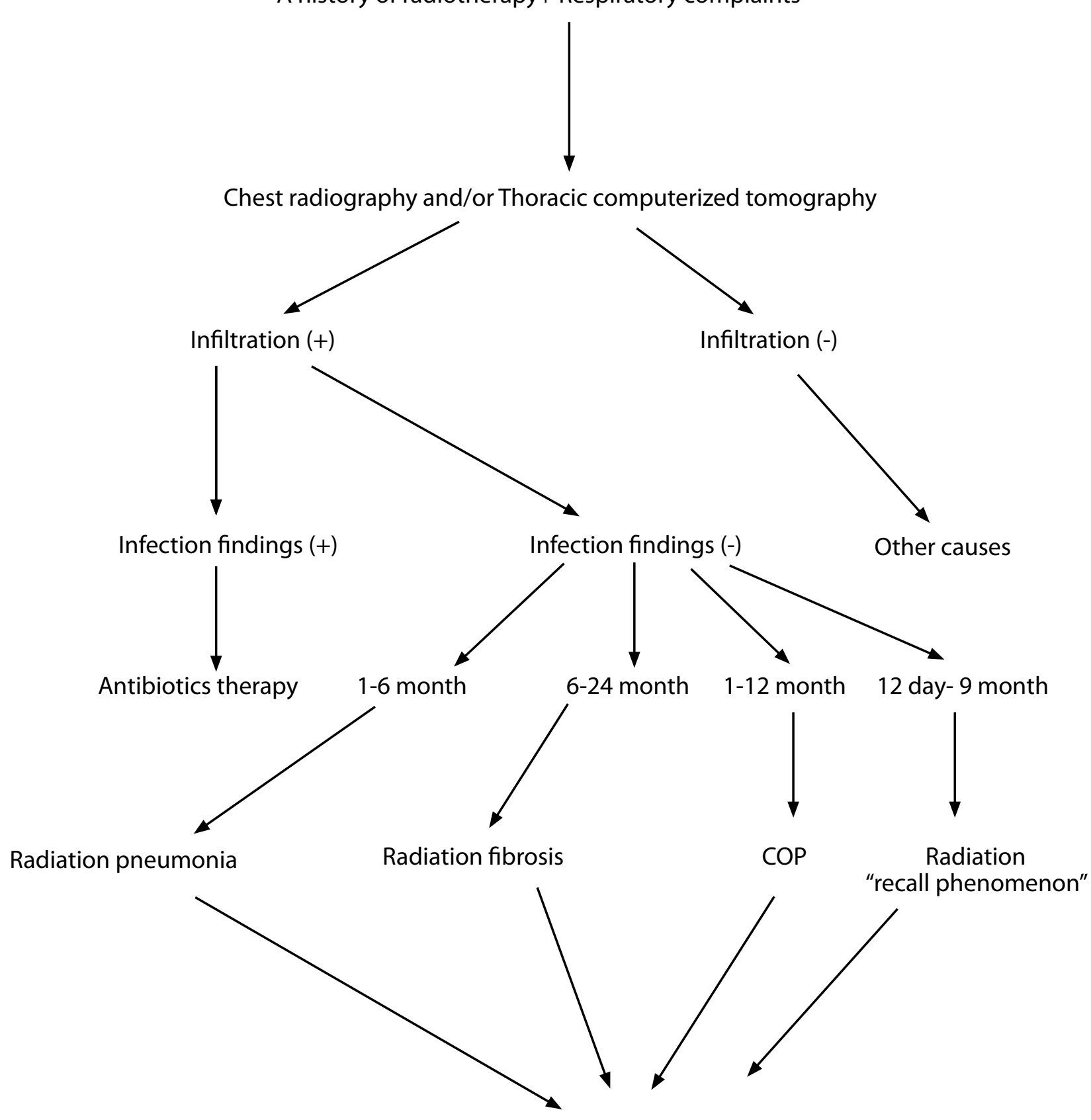

Treatment

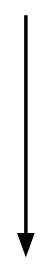

\section{Corticosteroid}


findings are a glassy appearance of the lung region being exposed to RT, diffuse infiltration, or consolidation. Patients have complaints of dry cough, mild fever, chest pain, and shortness of breath. Typically, RRF occurs following the first use of the trigger agent, but RRF developing after a couple of days has also been reported. In the literature, the time between the completion of RT and the occurrence of RRF was reported to be ranging from 12 days to 9 months. Treatment includes discontinuation of the trigger agent, the use of corticosteroid, and supportive care $(64,66)$.

\section{Other types of lung injury induced by radiation}

There is an increasing awareness that high-dose radiation can contribute to severe problems in the lung. One of the most scary complications is bronchopleural fistula, which is mostly seen in the postoperative period and is found at a significantly higher rate in patients having a history of RT or CT. In patients receiving neoadjuvant chemotherapy, the application of some methods, like intercostal flap, in order to improve bronchial stump decreases the risk for fistula (67).

In mediastinal malignancies (lung, esophagus, lymphoma, etc.), bronchoesophageal fistula (BEF) can occur secondary to RT. It is a life-threatening complication. The treatment approach is determined, depending on the severity of symptoms, localization of BEF, and general state of the patient. Self-expanding metallic stents, silicone esophageal prostheses, percutaneous gastrostomy, and surgical esophageal bypass can be administered in the treatment (68-71).

The risk rate for the development of pulmonary complications (massive hemoptysis, bronchial stenosis) is approximately $10 \%$ with endobronchial brachytherapy applied for the palliation of endobronchial obstructive malignant tumors (72). It can be difficult to distinguish the contribution of radiation from the effects of cancer in severe cases. In the final stage, similar side effects can be observed without the administration of brachytherapy because of the increased doses of external RT (73).

RT dose and concurrent $\mathrm{CT}$ can lead to unexpected complications. For instance, the increased traction due to radiation fibrosis can lead to the development of a cavity or pneumothorax (74).

\section{Prevention of lung injury associated with radiation}

In some studies, it was found that the administration of prophylactic amifostine during thoracic radiotherapy prevented radiation pneumonia $(75,76)$. However, these are preclinical data, and the use of amifostine is not a standard treatment that is recommended. Negative results have been obtained in some studies, including large series. Additionally, there are logistic and financial difficulties in the supply of amifostine. Moreover, amifostine has some side effects, such as nausea, exhaustion, and skin rashes (77).

Although it was specified that angiotensin-converting enzyme (ACE) inhibitors were effective in preventing radiation-induced lung injury in some animal studies, this result was confirmed clinically by a few studies. Its mechanism of action is not clear, but it was suggested that this result could result from their vasodilator effect on the vessel wall or antioxidant activity $(33,78-80)$.
It was reported in randomized controlled trials that the combination of pentoxifylline and vitamin $E$ decreased radiation-induced toxicity at the molecular level in normal tissue. In a study including cases with lung cancer, it was observed that radiation-induced toxicity decreased significantly in the group receiving a combination of pentoxifylline and vitamin E compared to the control group. Moreover, in another study, it was revealed that the use of only pentoxifylline decreased lung toxicity secondary to radiation in both the early stage and late stage. Especially in cases simultaneously exposed to chemoradiotherapy, which increases the risk for toxicity, it is specified that vitamin $E$ and pentoxifylline can be used $(81,82)$. It is thought that understanding the mechanism based on cytokine in radiation-induced lung injury can be solution options for treatment. TGF-beta is accepted to be the dominant profibrotic cytokine, and it can even be the cause of RP. Therefore, the interventions are for developing molecules with anti-TGF beta activity (83-85). The use of keratinocyte growth factor in mucositis developing in bone marrow transplantation is approved by the American Food and Drug Administration (FDA), and its preclinical trials have been continuing for RF (86).

In conclusion, various lung injury types, the radiation-related mechanism of which is still unclear, occur, and it is difficult to predict the risk factors for toxicity. Toxicities developing during radiotherapy administration are serious obstacles in applying the effective dose. The number of side effects can be reduced through dose control with modern RT techniques. However, there are insufficient data on this issue. Therefore, understanding the toxicities that are associated with RT will increase early diagnosis and treatment success.

\section{Peer-review: Externally peer-reviewed.}

Author Contributions: Concept - E.A., B.A.Y.; Design - E.A., B.A.Y; Supervision - H.C.H.; Funding - E.A., B.A.Y.; Materials - E.A., B.A.Y.; Data Collection and/or Processing - E.A., B.A.Y.; Analysis and/or Interpretation - H.C.H.; Literature Review - E.A., B.A.Y.; Writer - E.A., B.A.Y.; Critical Review - H.C.H.

Conflict of Interest: No conflict of interest was declared by the authors.

Financial Disclosure: The authors declared that this study has received no financial support.

\section{REFERENCES}

1. Machtay M. Pulmonary complications of anticancer treatment. In: Abelof MD, Armitage JO, Neiderhuber JE, Kastan MB, Mckenna WG, eds. Abelof's Clinical Oncology. 4th ed. Churchill Livingstone: Elsevier; 2008: 969-81. [CrossRef]

2. Graves PR, Siddiqui F, Anscher MS, Movsas B. Radiation pulmonary toxicity: from mechanisms to management. Semin Radiat Oncol 2010; 20: 201-7. [CrossRef]

3. Tezcan $Y$, Koç M. Torasik radyoterapiye bağlı toksisiteler. Turkiye Klinikleri J Thor Surg Special Topics 2012; 5: 267-71.

4. Zhao W, Robbins ME. Inflammation and chronic oxidative stress in radiation-induced late normal tissue injury: therapeutic implications. Curr Med Chem 2009; 16: 130-43. [CrossRef]

5. Wang J, Qiao XY, Lu FH, Zhou ZG, Song YZ, Huo JJ, Liu X. TGF-beta1 in serum and induced sputum for predicting radiation pneumonitis in patients with non-small cell lung cancer after radiotherapy. Chin J Cancer 2010; 29: 325-9. [CrossRef]

6. Wang $L, B i$ N. TGF-beta1 gene polymorphisms for anticipating radiation-induced pneumonitis in non-small-cell lung cancer: different ethnic association. J Clin Oncol 2010; 28: e621-2. [CrossRef] 
7. Anscher MS. Targeting the TGF-beta1 pathway to prevent normal tissue injury after cancer therapy. Oncologist 2010; 15: 350-9. [CrossRef]

8. Trott KR, Herrmann T, Kasper M. Target cells in radiation pneumopathy. Int J Radiat Oncol Biol Phys 2004; 58: 463-9. [CrossRef]

9. Fleckenstein K, Zgonjanin L, Chen L, Rabbani Z, Jackson IL, Thrasher B, et al. Temporal onset of hypoxia and oxidative stress after pulmonary irradiation. Int J Radiat Oncol Biol Phys 2007; 68: 196-204. [CrossRef]

10. Kufe D, Weichselbaum R. Radiation therapy: activation for gene transcription and the development of genetic radiotherapy-therapeutic strategies in oncology. Cancer Biol Ther 2003; 2: 326-9. [CrossRef]

11. Anscher MS, Peters WP, Reisenbichler H, Petros WP, Jirtle RL. Transforming growth factor beta as a predictor of liver and lung fibrosis after autologous bone marrow transplantation for advanced breast cancer. $\mathrm{N}$ Engl J Med 1993; 328: 1592-8. [CrossRef]

12. Madani I, De Ruyck K, Goeminne H, De Neve W, Thierens H, Van Meerbeeck J. Predicting risk of radiation-induced lung injury. JThorac Oncol 2007; 2: 864-74. [CrossRef]

13. Novakova-Jiresova A, Van Gameren MM, Coppes RP, Kampinga HH, Groen HJ. Transforming growth factor-beta plasma dynamics and post-irradiation lung injury in lung cancer patients. Radiother Oncol 2004; 71: 183-9. [CrossRef]

14. Rübe CE, Wilfert F, Palm J, König J, Burdak-Rothkamm S, Liu L, et al. Irradiation induces a biphasic expression of pro-inflammatory cytokines in the lung. Strahlenther Onkol 2004; 180: 442-8. [CrossRef]

15. Sekine I, Sumi M, Ito $Y$, Nokihara $H$, Yamamoto $N$, Kunitoh $H$, et al. Retrospective analysis of steroid therapy for radiation-induced lung injury in lung cancer patients. Radiother Oncol 2006; 80: 93-7. [CrossRef]

16. Tsoutsou PG, Koukourakis MI. Radiation pneumonitis and fibrosis: mechanisms underlying its pathogenesis and implications for future research. Int J Radiat Oncol Biol Phys 2006; 66: 1281-93. [CrossRef]

17. Faria SL, Aslani M, Tafazoli FS, Souhami L, Freeman CR. The challenge of scoring radiation-induced lung toxicity. Clin Oncol (R Coll Radiol) 2009; 21:371-5. [CrossRef]

18. Petit SF, Van Elmpt WJ, Oberije CJ, Vegt E, Dingemans AM, Lambin P, et al. [18F] fluorodeoxyglucose uptake patterns in lung before radiotherapy identify areas more susceptible to radiation-induced lung toxicity in non-small-cell lung cancer patients. Int J Radiat Oncol Biol Phys 2011; 81: 698-705. [CrossRef]

19. Takeda A, Ohashi T, Kunieda E, Sanuki N, Enomoto T, Takeda T, et al. Comparison of clinical, tumour-related and dosimetric factors in grade 0-1, grade 2 and grade 3 radiation pneumonitis after stereotactic body radiotherapy for lung tumours. Br J Radiol 2012; 85: 636-42. [CrossRef]

20. Jenkins $P$, Welsh $A$. Computed tomography appearance of early radiation injury to the lung: correlation with clinical and dosimetric factors. Int J Radiat Oncol Biol Phys 2011; 81: 97-103. [CrossRef]

21. Spych M, Gottwald L, Klonowicz M, Biegała M, Bibik R, Fijuth J. The analysis of prognostic factors affecting post-radiation acute reaction after conformal radiotherapy for non-small cell lung cancer. Arch Med Sci 2010; 6: 756-63. [CrossRef]

22. Kocak Z, Evans ES, Zhou SM, Miller KL, Folz RJ, Shafman TD, Marks LB. Challenges in defining radiation pneumonitis in patients with lung cancer. Int J Radiat Oncol Biol Phys 2005; 62: 635-8. [CrossRef]

23. Radiation Therapy Oncology Group: RTOG Acute Radiation Morbidity Scoring Criteria 2000. Available from http://www.rtog.org/members/ toxicity/acute.html.

24. Radiation Therapy Oncology Group: RTOG/EORTC Late Radiation Morbidity scoring Schema.2000.Available from http://www.rtog.org/members/toxicity/late.html.

25. Overgaard J, Bartelink H. Late effects consensus conference:RTOG/EORTC. Radiother Oncol 1995; 35: 1-82. [CrossRef]

26. Rubin P. Special issue: Late Effects of Normal Tissues (LENT) Consensus Conference. Int J Radiat Oncol Biol Phys 1995; 31: 1037-360. [CrossRef]
27. Trotti A, Colevas AD, Setser A, Rusch V, Jaques D, Budach V, et al. CTCAE v3.0: development of a comprehensive grading system for the adverse effects of cancer treatment. Semin Radiat Oncol 2003; 13: 176-81. [CrossRef]

28. Drzymala RE, Mohan R, Brewster L, Chu J, Goitein M, Harms W, et al. Dose-volume histograms. Int J Radiat Oncol Biol Phys 1991; 21: 71-8. [CrossRef]

29. Yuan S, Sun X, Li M, Yu J, Ren R, Yu Y, et al. A randomized study of involved-field irradiation versus elective nodal irradiation in combination with concurrent chemotherapy for inoperable stage III nonsmall cell lung cancer. Am J Clin Oncol 2007; 30: 239-44. [CrossRef]

30. Seppenwoolde Y, De Jaeger K, Boersma L, Belderbos JS, Lebesque JV. Regional differences in lung radiosensitivity after radiotherapy for non-small-cell lung cancer. Int J Radiat Oncol Biol Phys 2004; 60: 748-58. [CrossRef]

31. Oetzel D, Schraube P, Hensley F, Sroka-Pérez G, Menke M, Flentje M. Estimation of pneumonitis risk in three-dimensional treatment planning using dose-volume histogram analysis. Int J Radiat Oncol Biol Phys 1995; 33: 455-60. [CrossRef]

32. Kwa SL, Lebesque JV, Thuws JC. Radiation pneumonitis as a function of median lung dose. An analysis of pooled data of 540 patients. Int J Radiat Oncol Biol Phys 1998; 42: 1-9. [CrossRef]

33. Kharofa J, Cohen EP, Tomic $\mathrm{R}$, Xiang Q, Gore E. Decreased risk of radiation pneumonitis with incidental concurrent use of angiotensin-converting enzyme inhibitors and thoracic radiation therapy. Int J Radiat Oncol Biol Phys 2012; 84: 238-43. [CrossRef]

34. Brunelli A, Charloux A, Bolliger CT, Rocco G, Sculier JP, Varela G, et al. European Respiratory Society and European Society of Thoracic Surgeons joint task force on fitness for radical therapy. ERS/ESTS clinical guidelines on fitness for radical therapy in lung cancer patients (surgery and chemo-radiotherapy). Eur Respir J 2009; 34: 17-41. [CrossRef]

35. Shi A, Zhu G, Wu H, Yu R, Li F, Xu B. Analysis of clinical and dosimetric factors associated with severe acute radiation pneumonitis in patients with locally advanced non-small cell lung cancer treated with concurrent chemotherapy and intensity-modulated radiotherapy. Radiat Oncol 2010; 5: 35. [CrossRef]

36. Schild SE, McGinnis WL, Graham D, Hillman S, Fitch TR, Northfelt D, et al. Results of a phase I trial of concurrent chemotherapy and escalating doses of radiation for unresectable non-small-cell lung cancer. Int J Radiat Oncol Biol Phys 2006; 65: 1106-11. [CrossRef]

37. Bradley J, Graham MV, Winter K, Purdy JA, Komaki R, Roa WH, et al. Toxicity and outcome results of RTOG 9311: a phase I-II dose-escalation study using three-dimensional conformal radiotherapy in patients with inoperable non-small-cell lung carcinoma. Int J Radiat Oncol Biol Phys 2005; 61: 318-28. [CrossRef]

38. Cox JD, Azarnia N, Byhardt RW, Shin KH, Emami B, Pajak TF. A randomized phase I/II trial of hyperfractionated radiation therapy with total doses of $60.0 \mathrm{~Gy}$ to $79.2 \mathrm{~Gy}$ : possible survival benefit with greater than or equal to $69.6 \mathrm{~Gy}$ in favorable patients with Radiation Therapy Oncology Group stage III non-small-cell lung carcinoma: report of Radiation Therapy Oncology Group 83-11. J Clin Oncol 1990; 8: 1543-55.

39. Arrieta O, Gallardo-Rincón D, Villarreal-Garza C, Michel RM, Astorga-Ramos AM, Martínez-Barrera L, de la Garza J. High frequency of radiation pneumonitis in patients with locally advanced non-small cell lung cancer treated with concurrent radiotherapy and gemcitabine after induction with gemcitabine and carboplatin. J Thorac Oncol 2009; 4: 845-52. [CrossRef]

40. Blackstock AW, Ho C, Butler J, Fletcher-Steede J, Case LD, Hinson W, Miller AA. Phase la/lb chemo-radiation trial of gemcitabine and dose-escalated thoracic radiation in patients with stage III A/B non-small cell lung cancer. J Thorac Oncol 2006; 1: 434-40. [CrossRef]

41. Burstein HJ, Bellon JR, Galper S, Lu HM, Kuter I, Taghian AG, et al. Prospective evaluation of concurrent paclitaxel and radiation therapy after adjuvant doxorubicin and cyclophosphamide chemotherapy for Stage II or III breast cancer. Int J Radiat Oncol Biol Phys 2006; 64: 496-504. [CrossRef] 
42. Robnett TJ, Machtay M, Vines EF, McKenna MG, Algazy KM, McKenna WG. Factors predicting severe radiation pneumonitis in patients receiving definitive chemoradiation for lung cancer. Int J Radiat Oncol Biol Phys 2000; 48: 89-94. [CrossRef]

43. Vogelius IR, Bentzen SM. A literature-based meta-analysis of clinical risk factors for development of radiation induced pneumonitis. Acta Oncol 2012; 51: 975-83. [CrossRef]

44. Welker L, Jörres RA, Costabel U, Magnussen H. Predictive value of BAL cell differentials in the diagnosis of interstitial lung diseases. Eur Respir $J$ 2004; 24: 1000-6. [CrossRef]

45. Lopez Guerra JL, Gomez DR, Zhuang Y, Levy LB, Eapen G, Liu H, et al. Changes in pulmonary function after three-dimensional conformal radiotherapy, intensity-modulated radiotherapy, or proton beam therapy for non-small-cell lung cancer. Int J Radiat Oncol Biol Phys 2012; 83: e537-43. [CrossRef]

46. Çok G. Radyasyon pnömonisi, özefajiti ve bronşiti. Türk toraks derneği okulu. Available from: http://168.144.121.167/TORAKSFD23NJKL4NJ4H3BG3JH/10_kongre_kurs/pdf/447_454_Radyasyon_Pnomonisi.pdf

47. Mehta V. Radiation pneumonitis and pulmonary fibrosis in non-smallcell lung cancer: Pulmonary function, prediction, and prevention. Int J Radiation Oncology Biol Phys 2005; 63: 5-24. [CrossRef]

48. Fujino $M$, Shirato $H$, Onishi $H$, Kawamura $H$, Takayama $K$, Koto $M$, et al. Characteristics of patients who developed radiation pneumonitis requiring steroid therapy after stereotactic irradiation for lung tumors. Cancer J 2006; 12: 41-6. [CrossRef]

49. Gilroy SA, Bennett NJ. Pneumocystis pneumonia. Semin Respir Crit Care Med 2011; 32: 775-82. [CrossRef]

50. Wang S, Liao Z, Wei X, Liu HH, Tucker SL, Hu CS, et al. Analysis of clinical and dosimetric factors associated with treatment-related pneumonitis (TRP) in patients with non-small-cell lung cancer (NSCLC) treated with concurrent chemotherapy and three-dimensional conformal radiotherapy (3D-CRT). Int J Radiat Oncol Biol Phys 2006; 66: 1399-407. [CrossRef]

51. Muraoka T, Bandoh S, Fujita J, Horiike A, Ishii T, Tojo Y, et al. Corticosteroid refractory radiation pneumonitis that remarkably responded to cyclosporin A. Intern Med 2002; 41: 730-3. [CrossRef]

52. Mc Carty MJ, Lillis P, Vukelja SJ. Azathioprine as a steroid-sparing agent in radiation pneumonitis. Chest 1996; 109: 1397-400. [CrossRef]

53. Oymak FS, Demirbaş HM, Mavili E, Akgun H, Gülmez I, Demir R, et al. Bronchiolitis obliterans organizing pneumonia Clinical and roentrgenological features in 26 cases Respiration 2005; 72: 254-62. [CrossRef]

54. Arbetter KR, Prakash UB, Tazelaar HD, Douglas WW. Radiation-induced pneumonitis in the "nonirradiated" lung. Mayo Clin Proc 1999; 74: 27-36. [CrossRef]

55. Toma CL, Serbescu A, Alexe M, Cervis L, lonita D, Bogdan MA. The bronchoalveolar lavage pattern in radiation pneumonitis secondary to radiotherapy for breast cancer. Maedica (Buchar) 2010; 5: 250-7.

56. Nambu A, Araki T, Ozawa K, Kanazawa M, Ohki Z, Miyata K. Bronchiolitis obliterans organizing pneumonia after tangential beam irradiation to the breast: discrimination from radiation pneumonitis. Radiat Med 2002; 20: 151-4.

57. Cottin V, Frognier R, Monnot H, Levy A, DeVuyst P, Cordier JF; Groupe d'Etudes et de Recherche sur les Maladies "Orphelines" Pulmonaires. Chronic eosinophilic pneumonia after radiation therapy for breast cancer. Eur Respir J 2004; 23: 9-13. [CrossRef]

58. De Kruyff RH, Fang Y, Umetsu DT. IL-4-based helper activity of CD4+ T cells is radiation sensitive. Cell Immunol 1995; 160: 248-56. [CrossRef]

59. Azria $D$, Magné N, Zouhair $A$, Castadot $P$, Culine $S$, Ychou M, et al. Radiation recall: a well recognized but neglected phenomenon. Cancer Treat Rev 2005; 31: 555-70. [CrossRef]

60. Extermann $M$, Vogt N, Forni M, Dayer P. Radiation recall in a patient with breast cancer treated for tuberculosis. Eur J Clin Pharmacol 1995; 48: 77-8. [CrossRef]
61. Garza LA, Yoo EK, Junkins-Hopkins JM, VanVoorhees AS. Photo recall effect in association with cefazolin. Cutis 2004; 73: 79-85.

62. Parry BR. Radiation recall induced by tamoxifen. Lancet 1992; 340: 49. [CrossRef]

63. Abadir R, Liebmann J. Radiation reaction recall following simvastatin therapy: a new observation. Clin Oncol (R Coll Radiol) 1995; 7: 325-6. [CrossRef]

64. Schweitzer VG, Juillard GJ, Bajada CL, Parker RG. Radiation recall dermatitis and pneumonitis in a patient treated with paclitaxel. Cancer 1995; 76 : 1069-72. [CrossRef]

65. Azria D, Magné N, Zouhair A, Castadot P, Culine S, Ychou M, et al. Radiation recall: a well recognized but neglected phenomenon. Cancer Treat Rev 2005; 31: 555-70. [CrossRef]

66. Schwarte $\mathrm{S}$, Wagner $\mathrm{K}$, Karstens $\mathrm{JH}$, Bremer M. Radiation recall pneumonitis induced by gemcitabine Strahlenther Onkol 2007; 183: 215-7. [CrossRef]

67. Birdas TJ, Morad MH, Okereke IC, Rieger KM, Kruter LE, Mathur PN, Kesler KA. Risk factors for bronchopleural fistula after right pneumonectomy: does eliminating the stump diverticulum provide protection? Ann Surg Oncol 2012; 19: 1336-42. [CrossRef]

68. Argüder E, Aykun G, Karalezli A, Hasanoğlu HC. Bronchoesophageal fistula. J Bronchology Interv Pulmonol 2012; 19: 47-9. [CrossRef]

69. Chen YH, Li SH, Chiu YC, Lu HI, Huang CH, Rau KM, Liu CT. Comparative study of esophageal stent and feeding gastrostomy/jejunostomy for tracheoesophageal fistula caused by esophageal squamous cell carcinoma. PLoS One 2012; 7: e42766. [CrossRef]

70. Meyer J, Wahidi M, Shofer S, Evans J, Crawford J, Kelsey CR. Formation of a bronchoesophageal fistula following concurrent radiation and chemotherapy for lung cancer in the setting of Behçet's disease. J Thorac Oncol 2008; 3: 1361-2. [CrossRef]

71. Valenti V, Martínez-Cecilia D, Priego P, Cohen P, Martínez-Isla A. Bronchoesophageal fistula in a patient with non-Hodgkin's lymphoma. Clin Transl Oncol 2008; 10: 377-9. [CrossRef]

72. Ung YC, Yu E, Falkson C, Haynes AE, Stys-Norman D, Evans WK; Lung Cancer Disease Site Group Of Cancer Care Ontario's Program In Evidence-Based Care. The role of high-dose-rate brachytherapy in the palliation of symptoms in patients with non-small-cell lung cancer: a systematic review. Brachytherapy 2006; 5: 189-202. [CrossRef]

73. Miller KL, Shafman TD, Anscher MS, Zhou SM, Clough RW, Garst JL, et al. Bronchial stenosis: an underreported complication of high-dose external beam radiotherapy for lung cancer? Int J Radiat Oncol Biol Phys 2005; 61: 64-9. [CrossRef]

74. Okada M, Ebe K, Matsumoto T, Karino Y, Kawamura M, Tokuda O, et al. Ipsilateral spontaneous pneumothorax after rapid development of large thin-walled cavities in two patients who had undergone radiation therapy for lung cancer. Am J Roentgenol 1998; 170: 932-4. [CrossRef]

75. Sasse AD, Clark LG, Sasse EC, Clark OA. Amifostine reduces side effects and improves complete response rate during radiotherapy: results of a meta-analysis. Int J Radiat Oncol Biol Phys 2006; 64: 784-91. [CrossRef]

76. Koukourakis MI, Tsoutsou PG, Abatzoglou I. Computed tomography assessment of lung density in patients with lung cancer treated with accelerated hypofractionated radio-chemotherapy supported with amifostine. Am J Clin Oncol 2009; 32: 258-61. [CrossRef]

77. Han HS, Han JY, Yu SY, Pyo HR, Kim HY, Cho KH, et al. Randomized phase 2 study of subcutaneous amifostine versus epoetin-alpha given 3 times weekly during concurrent chemotherapy and hyperfractionated radiotherapy for limited-disease small cell lung cancer. Cancer 2008; 113: 1623-31. [CrossRef]

78. Ward WF, Molteni A, Ts'ao CH. Radiation-induced endothelial dysfunction and fibrosis in rat lung: modification by the angiotensin converting enzyme inhibitor CL242817. Radiat Res 1989; 117: 342-50. [CrossRef] 
79. Wang LW, Fu XL, Clough R, Sibley G, Fan M, Bentel GC, et al. Can angiotensin-converting enzyme inhibitors protect against symptomatic radiation pneumonitis? Radiat Res 2000; 153: 405-10. [CrossRef]

80. Kma L, Gao F, Fish BL, Moulder JE, Jacobs ER, Medhora M. Angiotensin converting enzyme inhibitors mitigate collagen synthesis induced by a single dose of radiation to the whole thorax. J Radiat Res 2012; 53: 10-7. [CrossRef]

81. Misirlioglu CH, Demirkasimoglu T, Kucukplakci B, Sanri E, Altundag K. Pentoxifylline and alpha-tocopherol in prevention of radiation-induced lung toxicity in patients with lung cancer. Med Oncol 2007; 24: 308-11. [CrossRef]

82. Ozturk B, Egehan I, Atavci S, Kitapci M. Pentoxifylline in prevention of radiation-induced lung toxicity in patients with breast and lung cancer: a double-blind randomized trial. Int J Radiat Oncol Biol Phys 2004; 58: 213-9. [CrossRef]
83. Kim JY, Kim YS, Kim YK, Park HJ, Kim SJ, Kang JH, et al. The TGF-beta1 dynamics during radiation therapy and its correlation to symptomatic radiation pneumonitis in lung cancer patients. Radiat Oncol 2009; 4: 59. [CrossRef]

84. Ao X, Zhao L, Davis MA, Lubman DM, Lawrence TS, Kong FM. Radiation produces differential changes in cytokine profiles in radiation lung fibrosis sensitive and resistant mice. J Hematol Oncol 2009; 2: 6. [CrossRef]

85. Arpin D, Perol D, Blay JY, Falchero L, Claude L, Vuillermoz-Blas S, et al. Early variations of circulating interleukin- 6 and interleukin-10 levels during thoracic radiotherapy are predictive for radiation pneumonitis. J Clin Oncol 2005; 23: 8748-56. [CrossRef]

86. Chen L, Brizel DM, Rabbani ZN, Samulski TV, Farrell CL, Larrier N, et al. The protective effect of recombinant human keratinocyte growth factor on radiation-induced pulmonary toxicity in rats. Int J Radiat Oncol Biol Phys 2004; 60: 1520-9. [CrossRef] 